\title{
Pupillary stress index: A new thermal comfort index for crossbred goats
}

\author{
José P. Lopes Neto ${ }^{1}$, Jordânio I. Marques ${ }^{1}$, Dermeval A. Furtado ${ }^{1}$, \\ Fernanda F. de M. Lopes ${ }^{2}$, Valéria P. Borges ${ }^{2} \&$ Tiago G. P. Araújo $^{3}$
}

${ }^{1}$ Universidade Federal de Campina Grande/Centro de Tecnologia e Recursos Naturais/Unidade Acadêmica de Engenharia Agrícola. Campina Grande, PB. E-mail: lopesneto@gmail.com (Corresponding author) - ORCID: 0000-0003-4960-5679; jordanioinacio@hotmail.com - ORCID: 0000-0002-76658218; araujodermeval@gmail.com - ORCID: 0000-0003-4511-571X

${ }^{2}$ Universidade Federal da Paraíba/Centro de Ciências Agrárias/Departamento de Solos e Engenharia Rural. Areia, PB. E-mail: fndlopes@gmail.com ORCID: 0000-0002-3766-675X; valpborges@gmail.com - ORCID: 0000-0002-2368-245X

${ }^{3}$ Universidade Federal de Campina Grande/Centro de Desenvolvimento do Semiárido/Unidade Acadêmica de Tecnologia do Desenvolvimento. Sumé, PB. E-mail: tiagoaraujo@yahoo.com - ORCID: 0000-0002-9383-560X

Key words:

physiology

pupillometry

thermal stress

physiological responses

\begin{abstract}
A B S T R A C T
Goats are homeothermic animals considered as rustic from the bioclimatic point of view, but the reduction of their productive efficiency may occur in unfavorable thermal conditions. The present study was carried out to evaluate pupil dilation as an indicator of thermal stress in Boer crossbred goats maintained under controlled environmental conditions. Six male crossbred goats of the Boer breed were distributed in a completely randomized design submitted to temperatures of 26,29 and $33^{\circ} \mathrm{C}$. The pupillary dilation and pupillary temperature, respiratory frequency, heart rate, surface and rectal temperatures were monitored. The significant increase in physiological responses occurred in response to the increase in air temperature. An increase of pupillary dilation was observed in the animals with the elevation of the air temperature, with an increase of $26.96 \mathrm{~mm}^{2}$ in pupillary area when comparing the temperatures 26 and $33^{\circ} \mathrm{C}$, and it was possible to establish a correlation between air temperature and pupillary diameter increase, named pupillary stress ratio (PSR).
\end{abstract}

\section{Palavras-chave:}

fisiologia

pupilometria

estresse térmico

respostas fisiológicas

\section{Índice de estresse pupilar: Um novo índice de conforto térmico para caprinos mestiços}

\section{R E S U M O}

Os caprinos são animais homeotérmicos considerados rústicos do ponto de vista bioclimático. Porém, em condições térmicas desfavoráveis, pode ocorrer a redução de sua eficiência produtiva. Realizou-se o presente estudo com o objetivo de avaliar a dilatação pupilar como indicador do estresse térmico em caprinos mestiços Boer, mantidos em condições ambientais controladas. Seis caprinos machos mestiços da raça Boer foram distribuídos em delineamento inteiramente casualizado e submetidos às temperaturas de 26,29 e $33^{\circ} \mathrm{C}$. Foram monitoradas a dilatação e temperatura pupilar, frequência respiratória, frequência cardíaca, temperatura superficial e retal. Ocorreu a elevação nas respostas fisiológicas em razão do aumento da temperatura do ar. Constatou-se aumento da dilatação pupilar dos animais com a elevação da temperatura do ar, observando-se um acréscimo de $26,96 \mathrm{~mm}^{2}$ de área pupilar quando comparadas às temperaturas de 26 e $33^{\circ} \mathrm{C}$, sendo possível estabelecer uma correlação entre temperatura do ar e aumento do diâmetro pupilar chamado de razão de estresse pupilar (REP). 


\section{INTRODUCTION}

The efficiency of animal production is increased when animals are in thermal comfort conditions, which allows allocating their reserves for their development (Souza et al., 2012). A relevant aspect for estimating stress in animals kept in unfavorable thermal environments is the observation of some physiological responses. However, the technological advances for the acquisition of these biological signs is still a great challenge and needs further development, and it can be affirmed that the recognition of these standards has not yet reached satisfactory levels (Pedrotti et al., 2014).

Research that relates pupillary dilation to stress and psychological factors in irrational animals is not commonly found, but in humans, studies have been developed for more than 50 years (Laeng et al., 2012). The pupil's reaction to light stimuli occurs to avoid excessive exposure and damage to the retina (Helene \& Helene, 2011), and is affected by factors such as excitement and stress. Pupillometry is a viable tool for the study of cognitive and emotional processes (Granholm \& Steinhauer, 2004).

In particular, the pupil has been shown to expand (mydriasis) as a consequence of mental effort and exposure to stressors (Pedrotti et al., 2014; Lempert et al., 2015). Therefore, it is hypothesized that there will be a substantial increase in the pupil size of the animals when subjected to thermal stress situations. Pupillometry will be one of the methods to be used in the future for not requiring direct contact of the operator with the animal, as well as for providing precise determinations, enabling the development of mathematical models for different levels of stress.

The objective of this study was to measure the pupil dilation of Boer + No Defined Racial Pattern (NDRP) in crossbred goats submitted to different temperatures in the climatic chamber, to correlate pupillary dilatation with the physiological responses and to establish patterns of variation with the thermal stress.

\section{Material AND Methods}

The experiment was carried out in the Laboratory of Rural Constructions and Environment (LaCRA) belonging to the Academic Unit of Agricultural Engineering (UAEA) of Campina Grande Federal University (UFCG), Campina

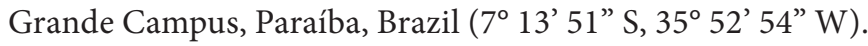

The procedures performed during this research were approved by the Research Ethics Committee (CEP) Protocol No. 284-2015. Six male crossbred goats from $3 / 4$ Boer breed and $1 / 4$ No Defined Racial Pattern (NDRP) were selected for breeding herds suitable for meat production, with an average weight of $25.06 \pm 4.43 \mathrm{~kg}$ and mean age of six months.

The animals were housed in metal stalls with dimensions $1.15 \times 0.50 \times 0.84 \mathrm{~m}$ in length, width and height, respectively, arranged inside a climatic chamber having $5.70 \mathrm{~m}^{2}$ of constructed area with $2.60 \mathrm{~m}$ height, where the animals were distributed in a completely randomized design with three treatments (air temperatures) and six replicates (animals). Animal feed and water were supplied unrestrictedly according to the composition indicated by the NRC (2007).
The values of air temperatures were defined based on the thermal comfort zone (TCZ) for goats mentioned by Souza et al. (2008), which is between 20 and $30{ }^{\circ} \mathrm{C}$ with relative air humidity between 50 and $70 \%$. Thus, the animals were submitted to three different mean controlled temperatures: $\mathrm{T} 1=26{ }^{\circ} \mathrm{C}$ (thermal comfort zone), $\mathrm{T} 2=29^{\circ} \mathrm{C}$ (temperature limit between comfort zone and thermal stress) and $\mathrm{T} 3=33$ ${ }^{\circ} \mathrm{C}$ (above TCZ) with $68 \%$ of relative humidity.

At each temperature in the climatic chamber, the animals were submitted to a program of $8 / 16 \mathrm{~h}$ (controlled temperature/ air temperature). After each controlled temperature period, the chamber was turned off and opened to the continuous 16 $\mathrm{h}$ period at environment temperature.

During the $8 \mathrm{~h}$ at controlled temperature, the illuminance inside the chamber was kept constant at $257 \mathrm{~lx}$ (measured with a portable digital lux meter) using two fluorescent lamps of $15 \mathrm{~W}$ each, in order to avoid interference in the pupil of the animal. The pupil images of animals were captured for the monitoring of their pupillary dilation during the 10 days of each treatment, during the period in which the chamber remained closed. The images were captured without direct contact with the animals and for this, hardware structures using proximity sensors HC-SR04 and Uno Arduino ${ }^{\circ}$ prototype board were mounted.

The data were extracted from the pupil size of the animals with the aid of a microcomputer, and due to the uniqueness of the goats' shape of the eyeball and pupil (ellipsoidal), the dimensions of the larger diameter (horizontal), smaller diameter (vertical) and pupillary area (Figure 1A) were collected. To obtain these pupillary dimensions, 30 photos of each animal in each treatment were selected for the analysis. The temperature of the animals was monitored over the pupil thermograms (Figure 1B) capturing the eyeball, using for this a thermographic camera in the three thermal conditions evaluated, adopting the 0.98 emissivity (emissivity of biological tissue).

In addition to the physiological responses of pupil dilation and temperature, data on respiratory frequency $(\mathrm{RF})$, heart rate (HR), skin surface temperature (ST) and rectal temperature (RT) were collected according to Lucena et al. (2013).

With the results of the pupillary area obtained in each situation, a thermal comfort index denominated Pupillary Stress Ratio (PSR) (Eq.1) was proposed, being calculated by the ratio of the pupillary area of the animal to the condition in which the reference pupillary area is found (animal in the condition of thermal comfort).

$$
\operatorname{PSR}=\frac{\mathrm{A}}{71.88}
$$

where:

PSR - pupillary stress ratio;

A - pupillary area in thermal stress condition, $\mathrm{mm}^{2}$; and,

71.88 - it corresponds to the pupillary area in thermal comfort condition for crossbred goats, $\mathrm{mm}^{2}$.

Three categories of physiological stress classification were proposed, due to the thermal discomfort for crossbred goats, 
A.

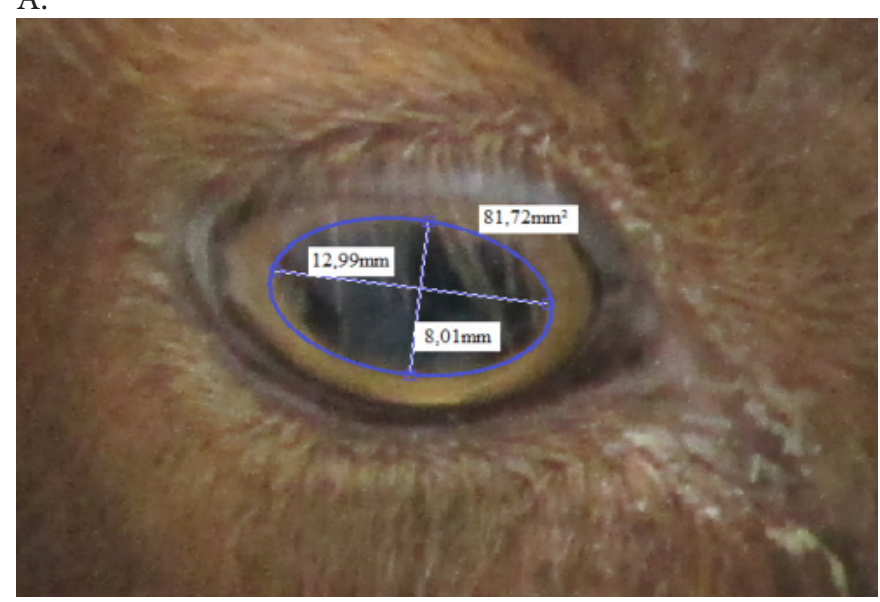

B.

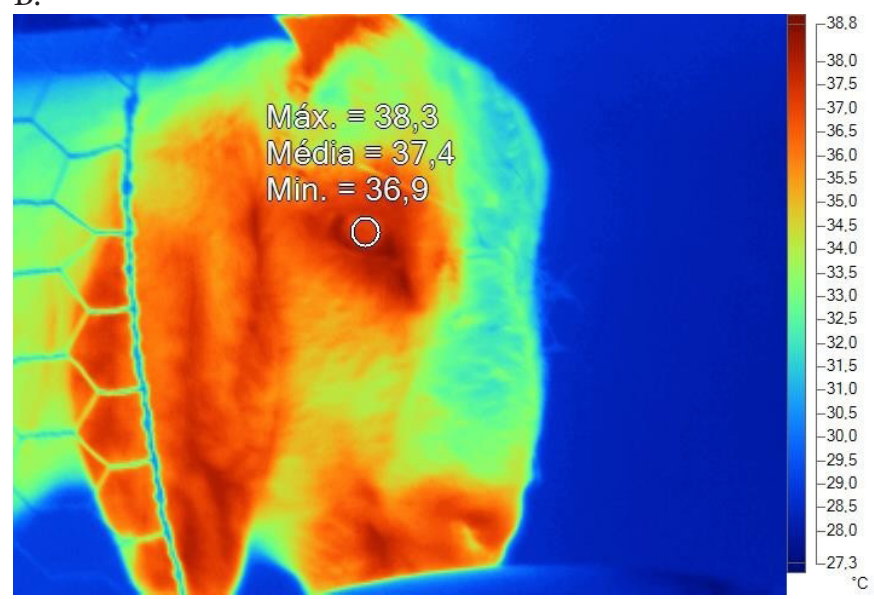

Figure 1. Pupillary measurements (A) and pupillary temperatures (B) of animals

taking into account the behavior of the PSR in the studied temperature ranges, being classified in thermal comfort, initial stress and full stress. Then, the feed conversion and weight gain were calculated based on the daily feed intake by the animals and their values were compared to the PSR.

Normality and hypothesis tests were performed by ANOVA using the Assistat statistical software (Silva \& Azevedo, 2016), where data were submitted to analysis of variance and $\mathrm{F}$ test. The Tukey test was used to compare means at 0.05 probability level. The normality of the data was verified through the Shapiro-Wilk test. Pearson's correlation test was applied for pupil dilatation, air temperature and physiological variables

\section{Results AND Discussion}

The values of the smaller diameter (d), larger diameter (D), area (A) and pupillary temperature (PT) of the animals followed by the respective standard deviations, in the three thermal conditions were evaluated. A significant increase in pupillary dimensions with increased air temperature is observed, indicating a direct relationship between peripheral vasodilation and the thermal environment (Table 1).

As regards the pupillary temperature, its significant value corresponding to the temperature of $29^{\circ} \mathrm{C}$ does not differ from the following $\left(33^{\circ} \mathrm{C}\right)$, which indicates that for an analysis of the thermal comfort for goats through pupillary temperature, it is
Table 1. Relationship between pupillary dimensions (Smaller (d) and larger (D) diameters, Area (A)) and pupillary temperature (PT) of goats

\begin{tabular}{ccccc}
\hline $\begin{array}{c}\text { AT } \\
\left({ }^{\circ} \mathrm{C}\right)\end{array}$ & $\mathbf{d}$ & $\mathbf{D}$ & $\begin{array}{c}\text { A } \\
\left(\mathrm{mm}^{2}\right)\end{array}$ & $\begin{array}{c}\text { PT } \\
\left({ }^{\circ} \mathrm{C}\right)\end{array}$ \\
26 & $7.68 \pm 0.27 \mathrm{c}$ & $11.90 \pm 0.20 \mathrm{c}$ & $71.88 \pm 2.79 \mathrm{c}$ & $35.13 \pm 0.48 \mathrm{~b}$ \\
29 & $8.51 \pm 0.17 \mathrm{~b}$ & $12.87 \pm 0.15 \mathrm{~b}$ & $86.10 \pm 1.05 \mathrm{~b}$ & $37.13 \pm 0.54 \mathrm{a}$ \\
33 & $9.20 \pm 0.33 \mathrm{a}$ & $13.67 \pm 0.33 \mathrm{a}$ & $98.84 \pm 3.36 \mathrm{a}$ & $37.71 \pm 0.29 \mathrm{a}$ \\
$\mathrm{CV}(\%)$ & 3.17 & 1.4 & 3.03 & 1.23 \\
\hline
\end{tabular}

Means followed by the same letters in a column do not differ significantly by the Tukey test $(p>0.05)$; C.V. - Coefficient of variation

possible to use a range between 26 and $29^{\circ} \mathrm{C}$ as the threshold for the occurrence of thermal stress.

It was observed that the area, smaller and larger diameter of the pupils of the animals had a significant difference $(\mathrm{p}<0.05)$ for the three air temperatures evaluated. An increase of $26.96 \mathrm{~mm}^{2}$ of the pupillary area was observed, which corresponds to an increase of $37 \%$ when compared to temperatures of $26^{\circ} \mathrm{C}$ (within the thermal comfort zone for goats) and $33^{\circ} \mathrm{C}$ (thermal stress condition), which evidences the influence of the ambient temperature on the pupillary reactions of the animals in study.

The dilation of the animals' pupils may be associated with the immediate activation of the neural axis, due to the thermal stress situation, which implies the activation mainly of the autonomic nervous system (sympathetic bundle) and the peripheral nervous system, which may lead to other physiological responses, to pupil dilation (Laeng et al., 2012). The autonomic nervous system is responsible for regulating the goat's body temperature and is controlled by the hypothalamus, which makes up the central control system, responsible for regulating the internal temperature of the animal's organism (McDougall et al., 2014).

Thus, the physiological changes in the animals, when subjected to temperature changes, are strongly related to the responses caused by the autonomic nervous system and can generate physiological changes due to the effort made by the animals in an attempt to keep the body temperature constant in response to the stressing variables (Silva et al., 2016).

The increase in air temperature also caused an increase in the animal's pupil surface temperature (Table 1 ), with a significant difference $(\mathrm{p}<0.05)$ at the temperature of $26^{\circ} \mathrm{C}$ in comparison to the two other air temperatures $\left(29\right.$ and $33^{\circ} \mathrm{C}$ ). This pupillary temperature elevation may be justified by increased blood supply to the ocular globe due to vasodilatation, which is a sensitive heat dissipation tool of the animals' body core (this should be kept within a narrow range of temperature), which intensifies due to the increase in air temperature.

Stewart et al. (2008) point out the pupillary temperature as an accurate measure for the measurement of stress in homoeothermic animals, since it is easily measured and without skin or hair interference, proving to be a more consistent measure of temperature changes than in other anatomical areas such as nose, ear, body and hoof as a response to stress. These authors suggest that increased pupil temperature as a result of stress occurs due to the corresponding increase in activities of the hypothalamic-pituitary-adrenal axis (HPA), which constitutes the central control system, responsible for regulating body temperature. 
It was possible to observe a similar trend of the RT and PT curves when the animals were submitted to thermal stress condition, with differences of 1.9 and $1.81^{\circ} \mathrm{C}$ between RT and $\mathrm{PT}$ at temperatures of 29 and $33^{\circ} \mathrm{C}$, respectively. Thus, it shows that $\mathrm{PT}$ is a variable capable of indicating sensitive variations in the body core temperature of the animals when they are maintained under conditions of thermal stress (Figure 2)

A sharp difference in the profile of the pupillary temperature curves and the average temperature of the surface of the other animal parts can also be noticed due to the direct influence of the ambient temperature on the ST variable, which occurs with less intensity in the PT.

The animals showed a significant respiratory frequency $(\mathrm{RF})(\mathrm{p}<0.05)$, higher as the air temperature distanced itself from the thermal comfort zone for goats, which according to Souza et al. (2008) is between 20 and $30^{\circ} \mathrm{C}$ (Table 2), which means that air temperature of $29^{\circ} \mathrm{C}$ represents alert status for goats.

In an experiment performed by Lucena et al. (2013), with native goats from the Northeast region in controlled environment, where four temperatures were evaluated (20.6; 24.8 and $27.8^{\circ} \mathrm{C}$ - all within the TCZ - and $31.6^{\circ} \mathrm{C}$ - above the TCZ), it was observed that there was no significant difference $(\mathrm{p}<0.05)$ in the HR between the temperatures considered comfortable for the animals, but there was a significant effect $(p<0.05)$ when these were compared with the stress temperature. These data corroborate with this study because, when the animals were subjected to $29^{\circ} \mathrm{C}$, they were in a moderate thermal stress condition, which is aggravated if the temperature increases to $33^{\circ} \mathrm{C}$.

The ST was influenced by air temperature, rising significantly $(\mathrm{p}<0.05)$ when compared to the means obtained in the three conditions evaluated (Table 2). According to Souza \& Batista (2012), the increase in the ambient temperature

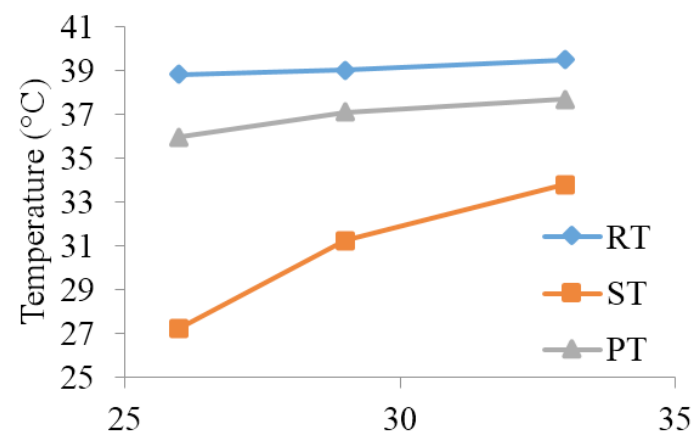

Air temperature $\left({ }^{\circ} \mathrm{C}\right)$

Figure 2. Rectal (RT), superficial (ST) and pupil temperature (PT) curves versus air temperature (AT)

Table 2. Respiratory frequency (RF), Heart rate (HR), Surface temperature (ST) and Rectal temperature (RT) of the animals for the conditions evaluated

\begin{tabular}{|c|c|c|c|c|}
\hline \multirow{2}{*}{$\begin{array}{l}\text { AT } \\
\left({ }^{\circ} \mathrm{C}\right)\end{array}$} & \multirow{2}{*}{$\begin{array}{c}\text { RF } \\
\left(\text { mov } \text { min }^{-1}\right)\end{array}$} & \multirow{2}{*}{$\begin{array}{c}\text { HR } \\
\text { (beat } \text { min }^{-1} \text { ) }\end{array}$} & ST & RT \\
\hline & & & \multicolumn{2}{|c|}{$\left({ }^{\circ} \mathrm{C}\right)$} \\
\hline 26 & $22.78 \pm 1.67 c$ & $100.67 \pm 3.48 c$ & $27.28 \pm 0.45 c$ & $38.84 \pm 0.08 b$ \\
\hline 29 & $28.28 \pm 3.62 b$ & $108.89 \pm 3.48 b$ & $31.27 \pm 0.41 b$ & $39.03 \pm 0.05 b$ \\
\hline 33 & $46.72 \pm 2.62 \mathrm{a}$ & $116.22 \pm 2.12 \mathrm{a}$ & $33.83 \pm 0.35 a$ & $39.52 \pm 0.19 a$ \\
\hline CV (\%) & 17.43 & 7.6 & 3.03 & 0.83 \\
\hline
\end{tabular}

Means followed by the same letters in a column do not differ significantly by the Tukey test $(p>0.05)$; C.V. - Coefficient of variation results in the superficial and endogenous heating of the animals caused by physiological and metabolic changes as an attempt to maintain the homeostasis of the metabolism.

The RT did not differ $(\mathrm{p}<0.05)$ with the air temperature increase from 26 to $29^{\circ} \mathrm{C}$; but in comparison with the ambient temperature of $33^{\circ} \mathrm{C}$, there was a significant increase $(\mathrm{p}<0.05)$. Despite the increase in rectal temperature, it is still within normal limits for the species. According to Dukes \& Swenson (2015), it can range from 38.5 to $39.7^{\circ} \mathrm{C}$. This means that, in order to maintain the RT within a narrow range of variation, the animals had to activate their heat exchange mechanisms, which can be evidenced by a significant increase of 105.10 ; 15.45 and $24.0 \%$ when compared to 26 and $33^{\circ} \mathrm{C}$ for RF, HR and ST, respectively.

When analyzing the dispersion diagram (Figure 3A), a high correlation between air temperature and pupillary dilatation was observed, and the linear behavior of the increase in the animals' pupillary area can be verified as the temperature of the environment increases with a coefficient of Pearson correlation ( $r$ ) between the two variables higher than 0.99 . It demonstrates that the measurement of pupillary dilation variation can be adopted as a good indicator of the level of thermal stress experienced by crossbred goats.

The dilation of the pupil also showed high positive linear correlations with the other animals' physiological responses (Figures 3B, C, D and E), with high correlation coefficients. Thus, the observation of pupillary dilatation is feasible in the description of the functioning of the autonomic thermoregulatory mechanisms of the Boer crossbred goats when subjected to thermal stress conditions, and can be used as a variable for the measurement of physiological responses in a non-invasive manner and with high degree of accuracy.

The pupillary stress ratio (PSR) proposed in Eq. 1 was calculated, resulting in $1 ; 1.19$ and 1.37 , respectively for the 3 treatments, representing a $19 \%$ increase from 26 to the $29^{\circ} \mathrm{C}$ and a $18 \%$ increase from 29 to $33^{\circ} \mathrm{C}$, with a total increase of $37 \%$ in PSR when compared to the 26 with the $33{ }^{\circ} \mathrm{C}$. When PSR varied within the range of 1.00 to 1.19 , it was categorized as a thermal comfort situation because this range of variation in the pupillary dilation ratio occurred when the animals were subjected to a thermoneutral condition $\left(26^{\circ} \mathrm{C}\right)$.

The range between 1.19 and 1.37 was classified as a transition zone between the comfort condition and thermal stress $\left(29^{\circ} \mathrm{C}\right)$, and when PSR was found to be greater than 1.37 , it indicated that the animals were in a full stress condition $\left(33^{\circ} \mathrm{C}\right)$, where they began to use their thermoregulation mechanisms more intensely and, consequently, releasing more energy for this.

In Figure 4, it can be observed that at the temperatures of 26 and $29^{\circ} \mathrm{C}$, where PSR ranged from 1.00 to 1.19 , there was no significant difference $(\mathrm{p}<0.05)$ between weight gain and feed conversion ratio. However, at $33^{\circ} \mathrm{C}$, a significant reduction ( $\mathrm{p}<0.05$ ) of $31.8 \%$ in the animals' weight gain can be verified, as well as the significant increase $(\mathrm{p}<0.05)$ that the animals reduced their feed conversion capacity, as the PSR distanced itself from the range classified as a thermal comfort zone. 


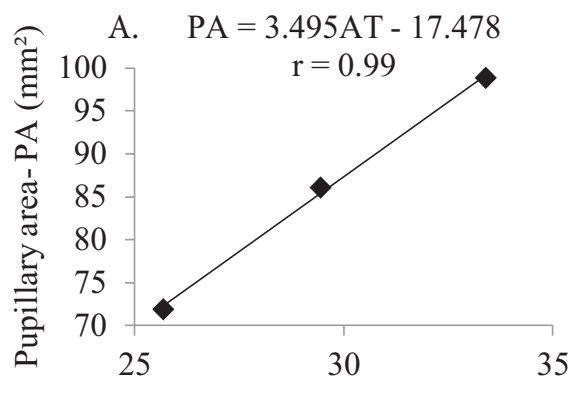

Air temperature $\left({ }^{\circ} \mathrm{C}\right)$
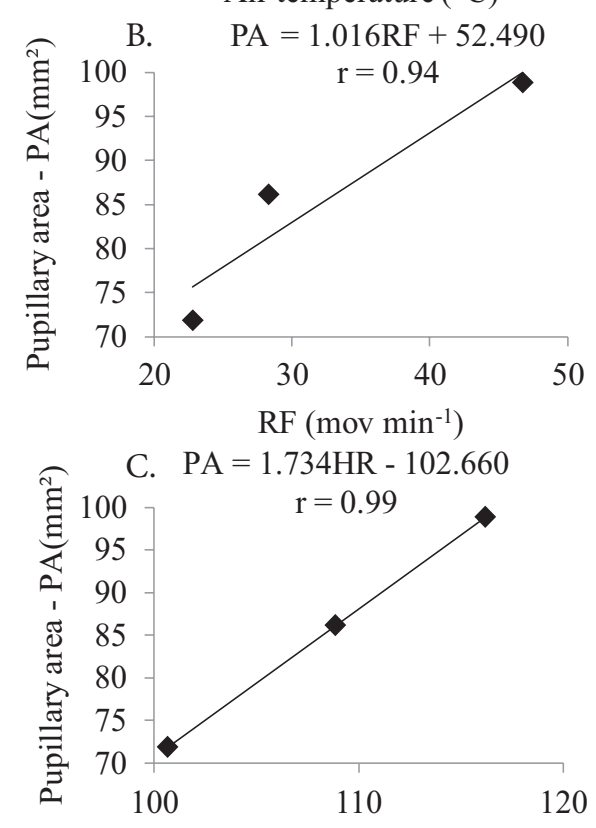

HR (beat $\min ^{-1}$ )
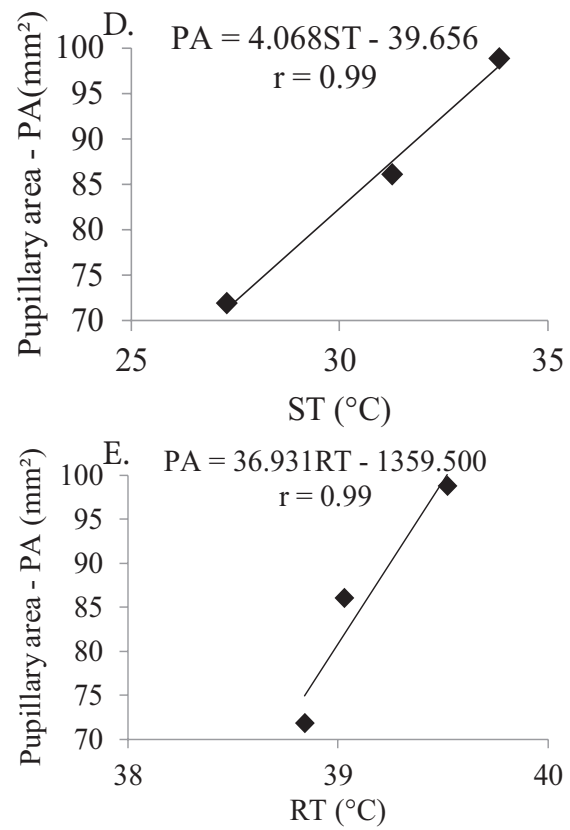

Figure 3. Correlation curves between the pupillary area and (A) air temperature and the physiological variables (B) frequency respiratory; (C) heart rate; (D) superficial temperature and $(\mathrm{E})$ rectal temperature

When studying the body weight gain and feed conversion of Boer crossbred goats, Tosto et al. (2010) considered to be satisfactory a feed conversion of up to 6.7. In the present research, it can be observed that the feed conversion was significantly elevated when the animals passed to the full stress PSR condition, which means the possibility of economic losses.

The categorization of these areas of thermal stress classification, based on the observation of pupil dilation, is important, which can allow the elaboration of equipment capable of observing the animal's pupil and generate immediate and precise responses in relation to the level of thermal discomfort imposed on the animals in the breeding environment. With this technological support the producers may speed up their decision making to improve the thermal comfort in the environment, resulting in the reduction of losses and increase animal productivity, enabling further exploration of the species.

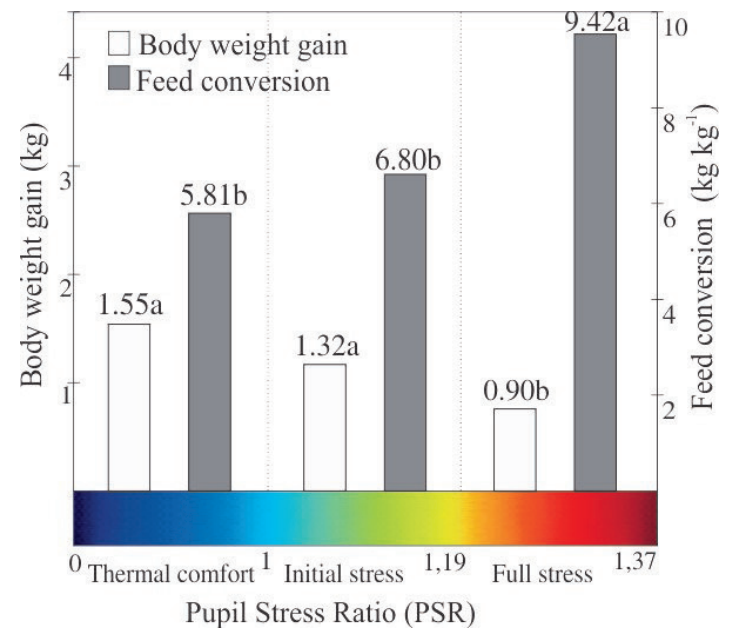

Figure 4. Relationship between pupil stress ratio (PSR) index and body weight gain and feed conversion

\section{Conclusions}

1. The elevation of the air temperature causes an increase in the pupillary area of the animals and, when subjected to the condition of thermal stress, their physiological responses increase.

2. The pupillary area has high coefficients of correlation with air temperature, respiration frequency (RF), heart rate (HR), surface temperatures (ST) and rectal temperatures (RT), respectively and it is possible to establish classification categories of the animals' thermal stress by means of the PSR index (pupillary stress ratio), with a range varying from thermal comfort to full stress.

3. The PSR can be adopted as an index for the measurement of the stress situation and how much this stress can influence the production responses of the animals.

\section{ACKnOWledgments}

To the Conselho Nacional de Desenvolvimento Científico e Tecnológico $(\mathrm{CNPq})$ for the scholarship granted and research funding (Process No 445393/2014-9).

\section{Literature Cited}

Dukes, H. H.; Swenson, H. J. Physiology of domestic animals. 1.ed. New Jersey: John Wiley, 2015. 800p. 
Granholm, E.; Steinhauer, S. R. Pupillometric measures of cognitive and emotional processes. International Journal of Psychophysiology, v.52, p.1-6, 2004.

Helene, O.; Helene, A. F. Some aspects of the optics of the human eye. Brazilian Journal of Physics Teaching, v.33, p.1-8, 2011.

Laeng, B.; Sirois, S.; Gredebäck, G. Pupillometry: The window to the preconscious? SAGE Journals, v.7, p.18-27, 2012.

Lempert, K. M.; Chen, Y. L.; Fleming, S. M. Relating pupil dilation and metacognitive confidence during auditory decision-making. Plos One, v.10, p.1-12, 2015.

Lucena, L. F. de A.; Furtado, D. A.; Nascimento, J. W. B. do; Medeiros, A. N. de; Souza, B. B. de. Physiological responses of native goats kept in thermoneutral temperature and thermal stress. Revista Brasileira de Engenharia Agrícola e Ambiental, v.17, p.672-679, 2013.

McDougall, S. J.; Münzberg, H.; Derbenev, A. D.; Zsombok, A. Central control of autonomic functions in health and disease. Frontiers in Neuroscience, v.8, p.440, 2014.

NRC - National Research Council. Nutrient requirements of small ruminants: Sheep, goats, cervids and new world camelids. Washington: National Academies Press, 2007. 384p.

Pedrotti, M.; Mirzaei, M. A.; Tedesco, A.; Chardonnet, J. R.; Mérienne, F.; Benedetto, S.; Baccino, T. Automatic classification stress analysis with pupil diameter. International Journal of HumanComputer Interaction, v.30, p.220-236, 2014.
Silva, F. de A. S. e; Azevedo, C. A. V. de. The Assistat software version 7.7 and its use in the analysis of experimental data. African Journal of Agricultural Research, v.11, p.3733-3740, 2016.

Silva, M. R. da; Souza, B. B. de; Guimarães, L. J.; Costa, D. F. da; Rock, E. F.; Souto, D. V. de O. S.; Silva, E. M. N. Heat stress and its influence on physiology of small ruminants. Journal of Animal Behaviour and Biometeorology, v.4, p.50-54, 2016.

Souza, B. B.; Batista, N. L. The effects of heat stress on animal physiology. Agropecuária Científica no Semiárido, v.8, n.3, p.6-10, 2012.

Souza, B. B.; Souza, D. E.; Silva, M. N.; Cesar, M. F.; Santos, J. R. S.; Smith, G. A. Physiological responses of goats from different genetic groups at Paraiban semiarid. Ciência e Agrotecnologia, v.2, p.314-320, 2008.

Souza, P. T. de; Salles, F. G. M.; Araújo, A. A. de. Impact of heat stress on the physiology, reproduction and production of goats. Ciência Rural, v.42, p.1888-1895, 2012.

Stewart, M.; Stafford, K. D.; Dowling, S. K.; Schaefer, J. R. Eye temperature and heat rate variability of calves with or without anesthetic disbudded site. Physiology \& Behavior, v.93, p.789797, 2008.

Tosto, M. S. L.; Araújo, G. G. L. de; Pereira, L. G. R.; Sousa, W. H.; Gonzalez, L. M.; Ribeiro, C. V. D. M. Ganho de peso e conversão alimentar de caprinos $1 / 2$ sangue Bôer alimentados com feno de erva-sal. In: Reunião Anual da Sociedade Brasileira de Zootecnia, 47, 2010, Salvador. Anais... Salvador: SBZ, 2010. CD-Rom 